\title{
Regulatory Impact Assessment in the Czech Republic ${ }^{\#}$
}

\author{
Leoš VÍTEK ${ }^{*}$
}

\section{Introduction}

Regulatory Impact Assessment (RIA) is usually based on a formalized system of ex ante and ex post evaluations of possible impacts associated with different types of regulations that potentially contribute towards fulfillment of the predetermined objectives. This approach possesses two advantages: first, it allows determining and measuring benefits and costs associated with the given type of regulation under assessment and second, it allows assessment of the best (most efficient) ways of their achievement. RIA therefore makes it possible to determine what type of regulation is best suited to achieve the intended goal. RIA also allows selecting regulations with the highest associated net present value of the benefits that accrue to all involved (regulated) subjects. The concept of a better (sometimes also "right", "good" or "smart") regulation is based on the American and British governmental policies of the late 1970s and 1980 s. It is also proposed as one of the tools promoting faster recovery of businesses from the aftermath effects of the 2008-09 financial crises and the following 2010-12 economic slowdown.

On the international dimension, RIA represents a standard procedure adopted by almost all countries. OECD (2009a) states that as of 2008, RIA has been adopted by 31 of its members and during the period 19752008 this number has grown by 29 countries. Since 1995, OECD presents to developed countries recommendations for implementation of so-called

\# The article is processed as an output of the research project Impact of tax and expenditure instruments on the microeconomic and macroeconomic efficiency registered by the University of Economics, Prague under the evidence registration number F1/30/2010.

Doc. Ing. Leoš Vítek, Ph.D. - associate professor; Department of Public Finance, Faculty of Finance and Accounting, University of Economics, Prague, Czech Republic; <leos.vitek@vse.cz>. 
"better regulation" that covers also an adoption and perfection of the RIA process. In recent years, it focuses mainly on the analyses of a good praxis (OECD 2010, 2010a) and improving tools and techniques related to the RIA process and its assessment (OECD 2009).

\section{Tab. 1: RIA process requirements in OECD countries}

\begin{tabular}{|c|c|c|c|c|c|c|c|c|c|c|}
\hline & 题 & 吕 & $\stackrel{20}{\mathscr{0}}$ & தి & 농 & ฮิ & ํํㅇ & ஜั & 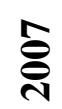 & ֻัे \\
\hline \begin{tabular}{|l|} 
No. of \\
countries
\end{tabular} & 2 & 4 & 8 & 9 & 10 & 22 & 28 & 30 & 30 & 31 \\
\hline
\end{tabular}

Source: OECD (2009a).

RIA is usually understood as a systematic tool and a decision process to examine and measure costs, benefits and impacts of new regulations. Using the RIA process can better carry out evidence-based policy making. The RIA process also improves transparency of government policies through consultation within other government branches and nongovernmental parts of the society.

The European Commission (EC) has started to conduct Business Impact Assessment in 1986. Since then, the EU has primarily focused on the implementation of RIA/IA at the level of Commission's proposals while the Member States are only provided with issued recommendations and invitations. The aim is to promote the so-called better regulation (more recently, "intelligent regulation") within the EU and thereby, from the supply side perspective, to facilitate economic growth. In 2007, the EC proposed and the Member States adopted a plan to improve by 2012 the regulatory environment (and thereby reducing the administrative burden by $25 \%$ ). In 2009 , the EC has modified the impact assessment system of its own proposals - see EC (2009). The latest initiative from the EC is the "Smart Regulation in the European Union" (EC, 2010). In this communication it is emphasized that an intelligent regulation applies to the whole policy origination cycle and views of those being regulated must play within the intelligent regulation a key role. In its communication, the EC announces an initiative to reduce regulatory impacts on small and medium businesses and outlines an analysis of the 'gold plating' problem (i.e. a situation when within the process of 
transposition or implementation of the EU legislation, requirements established on national levels exceed those set by the EU).

Tab. 2: RIA process requirements in OECD countries

\begin{tabular}{|c|c|c|c|c|c|c|}
\hline & 离章 & 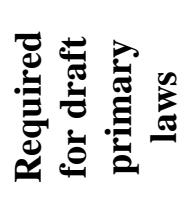 & 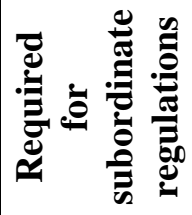 & 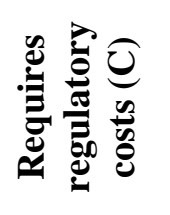 & 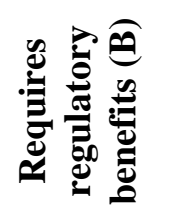 & 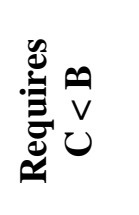 \\
\hline \begin{tabular}{|l|l|}
1998 \\
\end{tabular} & 10 & 16 & 16 & 16 & 15 & 11 \\
\hline 2005 & 24 & 27 & 25 & 29 & 29 & 18 \\
\hline 2008 & 29 & 29 & 29 & 31 & 31 & 21 \\
\hline
\end{tabular}

Source: OECD (2009a) and own calculation.

The topic of a better regulation is covered by a relatively extensive literature. The most recent example is e.g. Cordova-Novion and Jacobzone (2011) containing analysis and recommendations for strengthening the institutional capacity of regulatory reforms. Blind (2012) shows the influence of regulations on innovation, Gibbons and Parker (2012) reviews the work of the Regulatory Policy Committee in the UK.

OECD comprehensive and comparative papers by Parker and Kirkpatrick (2012), Radaelli and Fritsch (2012) and Coglianese (2012) provide a critical literature review of the theory and quantitative evidence of the impact of regulatory policy, appraise indicators suitable for measuring the performance of regulation programs and discuss the framework of systematical evaluation of the performance of regulations and regulatory policies. De Francesco et al. (2012) concentrate on the formulation of expectations about the political costs and benefits of different degrees of the implementation.

The theoretical article of Marneffe and Vereeck (2011) presents costs' taxonomy for RIA that takes into account all costs of the regulation (16 direct and two indirect regulatory cost types). Saurwein (2011) identifies factors that should be included in an effort to predict when alternative regulatory arrangements are likely to emerge and to be effective. Radaelli (2010) discusses four images of impact assessment: rational policy 
making, political control of the bureaucracy, public management reform and symbolic action. Jacobzone et al. (2010) estimates impact of the quality of governmental regulation on the economic performance and establishes that improving the quality of the regulatory framework supports the growth of employment as well as GDP in the business sector. The time aspect related to valuation is dealt in Kubíček and Vítek (2010). Radealli (2010a) provides empirical analysis of RIA processes on Canada, Denmark, the Netherlands, Sweden, the United Kingdom, the United States, and the EU. Zhang (2010) looks at the regulatory reform in selected countries in Asia and Africa; it is found that the regulatory reform in these countries has not shifted from making ad hoc improvements to systematic regulatory structures. At the EC level, the most recently published Commission's Communication (EC, 2010) focuses on the concept of a so-called intelligent or smart regulation.

Assessment of options, various techniques and methods of specifying the costs and benefits together with their quantification within the Czech and Slovak conditions has been described in Staroňová (2010) and Ochrana (2005). This article further develops the text published in Vítek (2010, 2011).

The aim of the presented article is to explore the RIA process following the first years of its operation and to analyze the quality of work of the government institutions in this field. To achieve this objective, we will process government committee minutes and describe trends over the years 2008-2012.

The structure of the presented paper is as follows: after introduction, we will focus on procedural and institutional settings of the Regulatory Impact Assessment in the Czech Republic. Furthermore, we will focus our attention on the operation of the RIA in the Czech Republic during the period 2008-2012 and the quality and risks of the regulatory impact assessment. Conclusions summarize the obtained results.

\section{Procedures and Operations of the RIA in the Czech Republic}

In the Czech Republic, the RIA has been discussed since OECD recommendations for a better regulation (2000-2005). Since 2005, RIA 
has become a part of the legislative process and since 2007 the General principles of RIA has been adopted (UV 2007, 2007a). At the same time, the Panel for a Regulatory Reform and Effective Public Administration and the Committee for Quality Control of the Regulatory Impact Assessment had been established. The Report on efficiency of the General principles of RIA has been issued in 2009 (MV 2009, 2009a) and in 2011 the new General principles of RIA has been adopted (UV 2012a). At the same time has also been established a new Committee of the Legislative Council of the Government for RIA quality.

\section{Years 2007-2011}

Fundamental elements of the regulatory impact assessment in the Czech Republic included during the period 2007-2011: formulation of the governmental objectives,

1. "small" RIA;

2. material intent of the Act;

3. governmental approval;

4. "large" RIA;

5. paragraph wording of the Act;

6. approval by the Government and the Parliament;

7. implementation;

8. assessment.

Compared to the OECD-recommended conventional impact assessment procedure, the Czech implementation inserted into the decision-making process an intermediate step, the so-called small RIA. The aim was to capture, already within the preparatory stage of the given act's material intent, different ways of reaching the intended targets while limiting the RIA-associated excessive burden on the state administration. The reason behind was that the small RIA - as opposed to the large RIA does not have to include detailed quantification of regulatory costs and benefits; the focus is rather on identification of various groups involved in individual variants.

The RIA procedure is in the Czech Republic performed for all draft legislation prepared by the central government administration, including implementations of EU regulations. There were also exceptions under which the RIA process does not have to be carried out, especially in 
situations of crises, urgent cases of a threat of significant economic or other losses, or in the case of general procedural rules.

Compared to the small regulatory impact assessment, the large RIA had been performed only in cases of regulations with a cumulative impact exceeding CZK 140 million. The large RIA was not obligatory for tax rate modifications, changes in the volume of benefits, insurance or pensions, etc. It is important that the large RIA was not mandatory for draft regulations implementing the European legislation.

Coordination of the RIA process was during 2007-2011 secured by the "Panel for a Regulatory Reform and Effective Public Administration" (hereinafter the Panel). The Panel adopted opinions on legislative proposals via assessment of their impacts, including the administrative burden caused, and approves exceptions from the RIA implementation requirements. The Panel's permanent committee was the "Committee for Quality Control of the Regulatory Impact Assessment" (hereinafter the Committee).

Regulatory impact assessment is in the Czech Republic really performed since 2008. The Committee proposes opinions on the draft legislation liable to RIA. The draft opinions are submitted to the Panel for an approval. General statistics of the legislation under review is summarized in the Table 3.

\section{Years 2011-2012}

The first evaluation of RIA has been in the Czech Republic carried in 2008. As main weaknesses were already within this initial years considered the formalism of RIA and a weak level of independence of the RIA quality assessment. Therefore, in December 2011 were the rules and institutions of RIA reformed with the aim to (i) reduce the formality of RIA, (ii) remove exemptions from the obligation to carry out RIA, (iii) perform RIA already at the inception of the debate on regulation and (iv) strengthen the independence of the RIA quality control.

The main elements of the regulatory impact assessment in the Czech Republic since 2011 include: 
- for every legal regulation draft must be put together a standardized "impact overview",

- for regulations with large impacts must be carried out RIA (noted in the Plan of the governmental legislative work or recorded in a separate governmental resolution),

- RIA must be carried out for each factual legal intention,

- prior to the governmental discussion, the quality of the "Final RIA report" is assessed by the working committee for RIA (new Committee); in case of a negative opinion, the material is returned for an additional revision / rewriting; no proposal that did not obtain the RIA approval may continue within the legislative process,

- the result is the "Final RIA report", presented to the government.

Tab. 3: RIA of the legislation in 2008-11: number of proposals (NoP)

\begin{tabular}{|l|r|r|r|r|r|}
\hline & $\begin{array}{c}\text { NoP liable to } \\
\text { RIA reviewed by } \\
\text { the Committee }\end{array}$ & $\begin{array}{c}\text { recommended by } \\
\text { re Committee } \\
\text { for approval }\end{array}$ & \multicolumn{2}{|c|}{$\begin{array}{c}\text { NoP with RIA } \\
\text { performed }\end{array}$} \\
\hline $\mathbf{2 0 0 8}$ & 155 & 144 & $92.9 \%$ & 69 & $44.5 \%$ \\
\hline $\mathbf{2 0 0 9}$ & 116 & 107 & $92.2 \%$ & 71 & $61.2 \%$ \\
\hline $\mathbf{2 0 1 0}$ & 146 & 136 & $93.2 \%$ & 104 & $71.2 \%$ \\
\hline $\mathbf{2 0 1 1}$ & 101 & 94 & $93.1 \%$ & 80 & $79.2 \%$ \\
\hline
\end{tabular}

Source: own processing based on data MV ČR (2011).

Approximately $90 \%$ of the submitted draft legislation liable to RIA was recommended for approval. This share, however, paradoxically slightly increased over the time. This corresponds with an intuitive logic and assumption that the number of procedural standards does not increase, except for the RIA. A possible explanation for the decline may also be in a growing number of regulations asserting an exception due to the implementation of European regulations (EU re regulations require only small RIA).

The usual reason behind disapproving recommendations related to submitted proposals was most often insufficient quality of the performed RIA or an unfounded exemption from the RIA performance. Ratio of the 
number of legislative proposals in which the RIA was actually performed to the number of proposals liable to RIA grows on the y-o-y basis during the period 2008-2011 (from 92.9\% to $93.1 \%$ ). In the remaining cases, the submitting body of a proposed legislation has exerted some form of exception from the implementation of RIA - the most frequently applied exemptions from the implementation of RIA were cases of legislative proposals representing a mere technical amendment of the existing legislation and proposals that represented general procedural rules or their modifications.

Fig. 1: The most frequently applied exemptions from the RIA implementation in 2008-2011

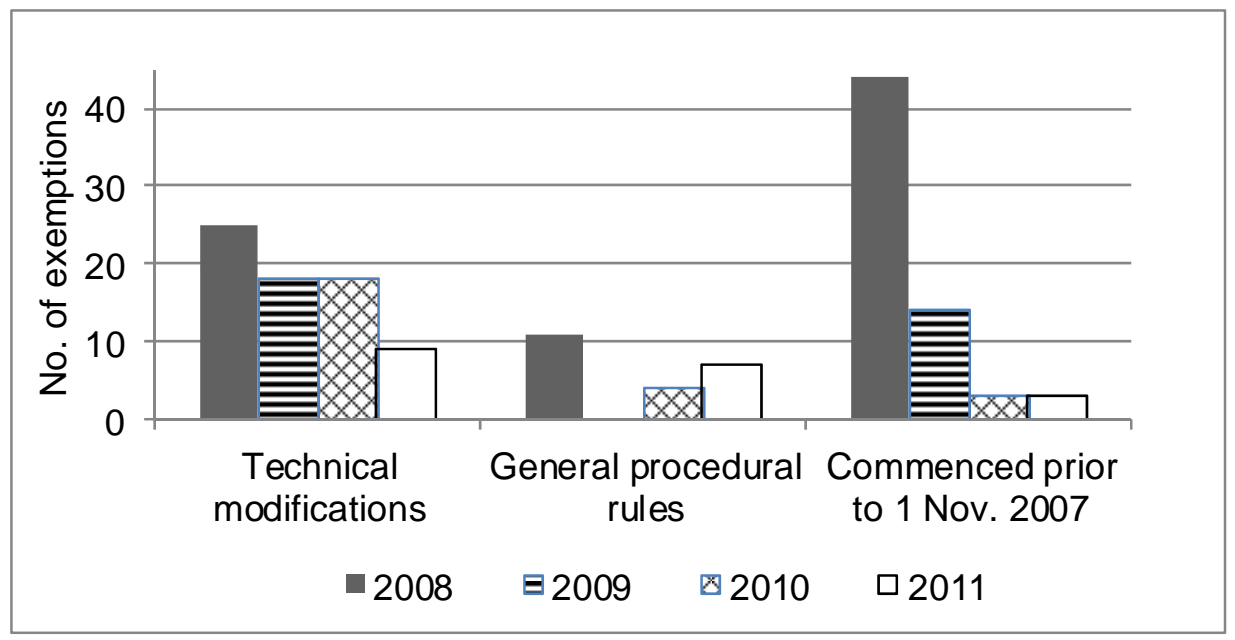

Source: own processing based on MV ČR (2011).

In 2008, when the applied exceptions occurred in 86 cases (i.e. 55\%), the most frequently cited exception has been that of an initiation of the preparatory legislative stage prior to 1 November 2007. In order to exercise this exception, initiation of the legislative work must be provable.

The bodies with the highest number of comments submitted towards the performed RIA included the Ministry of the Interior, which until 2011 had a department dealing with the RIA (since autumn 2011 it was back to the Cabinet Office, where it has been until 2006/2007). The most frequently reported comments to the performed RIA included insufficient variability in solutions, absented quantifications of proposed variants' impacts, exclusion of certain groups of subjects affected by the legislation, etc. 
Minutes from the Committee meetings indicate that the majority of the performed RIA was performed in the so-called small RIA format under which detailed quantification of benefits and costs is not required only their identification. This deficiency was in turn subjected to comments within the inter-departmental debate procedure that was not always being settled. These situations are thus inconsistent with the procedural rules of the RIA implementation that stipulate that the legislative proposal may never be processed prior to the RIA.

Tab. 4: Impact assessment of the legislation I-X 2012 (NoP)

\begin{tabular}{|c|c|c|c|r|}
\hline $\begin{array}{c}\text { Year/ } \\
\text { months }\end{array}$ & $\begin{array}{c}\text { NoP liable to } \\
\text { RIA reviewed by } \\
\text { the Committee }\end{array}$ & $\begin{array}{c}\text { NoP } \\
\text { without } \\
\text { objections }\end{array}$ & $\begin{array}{c}\text { NoP with } \\
\text { the request } \\
\text { for change }\end{array}$ & $\begin{array}{c}\text { NoP } \\
\text { finally } \\
\text { rejected }\end{array}$ \\
\hline 2012/I-X & 84 & $16(19.0 \%)$ & $68(81.0 \%)$ & 0 \\
\hline
\end{tabular}

Source: own processing based on data UV (2012b).

Table 5 shows the RIA process following the reform of its rules at the end of 2011. The change in the Committee and its rules are reflected in the minutes of its meetings. Although the change in the structure of minutes does not allow for a direct comparison of the years 2008-2011 with the year 2012, there is clearly visible a change: compared to the 92 93\% success rate of RIA proposals within the 2008-2011 system, the primary success rate of RIA proposals has in 2012 fallen to just 19\%. Towards the remaining $81 \%$ proposals had the new Committee issued comments. On the other hand, there has not yet been a definitive rejection of any draft RIA: ultimately, the proposal is always either returned for a revision or accepted, but it has never been definitively rejected. The reason may also be the fact that the government sometimes discusses (and even accepts) proposals for which is the opinion of the new Committee with respect to the draft RIA a relatively negative one. 
Tab. 5: Impact assessment of the legislation I-X 2012 (NoP)

\begin{tabular}{|l|r|r|r|r|r|r|}
\hline $\begin{array}{l}\text { Year / } \\
\text { months }\end{array}$ & \multicolumn{1}{|c|}{ A } & \multicolumn{1}{c|}{ B } & \multicolumn{1}{c|}{ C } & \multicolumn{1}{c|}{ D } & \multicolumn{1}{c|}{ E } & \multicolumn{1}{c|}{ F } \\
\hline $\mathbf{2 0 1 2}$ / I-X & 68 & 7 & 43 & 1 & 13 & 4 \\
\hline \% & 100 & 10.3 & 63.2 & 1.5 & 19.1 & 5.9 \\
\hline
\end{tabular}

$\mathrm{A}=$ Number of proposals (NoP) with the request for a change; $\mathrm{B}=\mathrm{NoP}$ with the request for a change (but without revision or rewriting); $\mathrm{C}=\mathrm{NoP}$ recommended for a revision without the need of resubmitting; $\mathrm{D}=$ Proposals recommended for a revision with the need of resubmitting; $\mathrm{E}=$ Proposals recommended for a rewriting without the need of resubmitting; $\mathrm{F}=$ Proposals recommended for a rewriting with the need of resubmitting.

Source: own processing based on data UV (2012b).

Substantial part of RIA drafts towards which the new Committee has comments is returned to be revised (but not completely rewritten). On the whole, comments were filed with respect to $63 \%$ of RIA drafts. Even revised RIA drafts were over the monitored period mostly excluded from further discussions of the new Committee. The reason, however, may also be a too short reference period, over which returned drafts may still be processed.

MV (2008, 2009, 2009a) and Vítek (2011) consider as main risks of the RIA process in the Czech Republic similar factors: formalism, lack of quantification of benefits and costs, lack of independent evaluation of quality and unsystematic and insufficient inputs. On the other hand, it is necessary to take into account the risk that impact assessment based solely on external subjects would lead to an overly academic view or to a disproportionate emphasis on negative aspects of regulation by private subjects that are potentially negatively affected by the given regulation. Another risk of RIA are excessive costs of its implementation - e.g. at the central level of the state administration, annual labour costs for the Czech Republic may be estimated at the level of ca. CZK 200 million. Possible solution of the costs and regulation-associated risks represents also slowing down of the legislative process and thus limiting the number of new regulations. 


\section{Conclusions}

Over the past decade, the vast majority of developed countries has introduced or developed a formalized system of governmental regulation impact assessment (RIA). The Czech Republic has followed these countries and in 2007/2008 it has also introduced the RIA process of a similar format. The process administration of RIA was in the first phase entrusted to the Panel for a Regulatory Reform and Effective Public Administration and its permanent Committee for Quality Control of the Regulatory Impact Assessment. The Committee checked the accuracy and quality of the performed RIA that is in the Czech Republic compulsory for all generally binding legal regulations proposed by ministries and other central administrative authorities.

Although the regulation is assessed mainly ex ante, it is possible to observe a shift in a positive direction, both in the quality of the processed RIA by individual departments and also in their approach to RIA (staying away from asserting exemptions to RIA implementation at all costs, understanding RIA as a way to improve regulation, etc.). As a disadvantage of the previous RIA process was the option to perform only a reduced version of the RIA, the so-called small RIA, which required only qualitative assessment without comparing benefits and costs of various options. This approach was supportive to formalism and verbal evaluation of regulatory alternatives and prevented ex-ante and notably ex post efficiency assessment of the proposed and adopted regulations.

As a solution to these problems, towards the end of 2011 were modified RIA rules and the institutional affiliation of the new Committee. The Committee is now staffed only by experts (notably academics) outside of the state administration and its activities are secured by the secretariat of the Office of the Government. The new rules limit the RIA obligation only to new factual legal intentions and extensive new regulations. At the same time a new rule has been adopted: the summary of impact assessments must be carried out even before the work on a new regulation is initiated.

General statistics for the period 2008-2011 points at a gradual decrease in the number of legislations assessed from the RIA perspective. On the other hand, the number of proposals that were not recommended by the Committee for an approval decreased from $7.1 \%$ in 2008 to $6.9 \%$ in 
2010. It could indicate a mildly decreasing pressure on the quality of the performed assessments. In 2012, following the reform of RIA rules, there came to a dramatic increase in demandingness with respect to the assessment of RIA drafts: the primary success rate of RIA drafts has fallen to just $19 \%$. The remaining $81 \%$ of drafts were commented by the Committee.

A more detailed evaluation of the new rules' performance asks for an extended period of time. Already now, however, it shows that the strengthening of Committee's independence has led to a stricter assessment of the RIA proposals. The key question now remains to what extent will the governmental cabinet reflect negative views of the Committee towards new regulation proposals?

\section{References:}

[1] Blind, K (2012): The Influence of Regulations on Innovation: A Quantitative Assessment for OECD Countries. Research Policy, 2012, vol. 41, no. 2, pp. 391-400.

[2] Coglianese, C. (2012): Evaluating the Impact of Regulation and Regulatory Policy. OECD Regulatory policy Expert Paper No. 1. Paris, Organization for Economic Co-operation and Development, 2012.

[3] Cordova-Novion, C. - Jacobzone, S. (2011): Strengthening the Institutional Setting for Regulatory Reform: The Experience from OECD Countries. OECD Working Papers on Public Governance No. 19. Paris, Organization for Economic Co-operation and Development, 2011.

[4] De Francesco, F. - Radaelli, C. M. - Troeger, V. E. (2012): Implementing regulatory innovations in Europe: the case of impact assessment. Journal of European Public Policy, 2012, vol. 19, no. 4, pp. 491-511.

[5] EC (2009): Impact Assessment Guidelines. SEC (2009) 92. Brussels, European Commission, 2009.

[6] EC (2010): Smart Regulation in the European Union. COM(2010)543. Brussels, European Commission, 2010. 
[7] Gibbons, M. - Parker, D. (2012): Impact assessments and better regulation: the role of the UK's Regulatory Policy Committee. Public money \& Management, 2012, vol. 32, no. 4, pp. 257-264.

[8] Jacobzone, S. et al. (2010): Assessing the Impact of Regulatory Management Systems: Preliminary Statistical and Econometric Estimates. OECD Working Papers on Public Governance no. 17. Paris, Organization for Economic Co-operation and Development, 2010.

[9] Kubíček, J. - Vítek, L. (2010): Hodnocení veřejných projektů z hlediska společenské míry diskontace. Politická ekonomie, 2010, vol. 58, no. 3, pp. 291-304.

[10] Marneffe, W. - Vereeck, L. (2011): The meaning of regulatory costs. European Journal of Law and Economics, 2011, vol. 32, no. 3, pp. 341-356.

[11] MV (2008): Hodnocení dopadì právni regulace - zkušenosti a poznatky ve státní správě a př́klady dobré praxe za obdobi od počátku roku 2008 [online]. Praha, Ministry of the Interior of the Czech Republic, [cited $11^{\text {th }}$ September, 2012],

$<$ http://www.mvcr.cz/clanek/hodnoceni-dopadu-regulace-ria602648.aspx?q=Y2hudW09Ng\%3d\%3d>.

[12] MV (2009): Informace o realizaci hodnocení dopadi regulace (RIA) $v$ legislativním procesu do 31. května 2008 [online]. Praha, Ministry of the Interior of the Czech Republic, [cited $11^{\text {th }}$ September, 2012], $<$ http://www.mvcr.cz/clanek/hodnoceni-dopadu-regulace-ria602648.aspx?q=Y2hudW09Ng\%3d\%3d $>$.

[13] MV (2009a): Zpráva o účinnosti Obecných zásad pro hodnocení dopadi regulace v roce 2008 [online]. Praha, Ministry of the Interior of the Czech Republic, [cited $11^{\text {th }}$ September, 2012], $<$ http://www.mvcr.cz/clanek/hodnoceni-dopadu-regulace-ria602648.aspx?q=Y2hudW09Ng\%3d\%3d>.

[14] MV (2011): Závěry jednání Grémia pro regulační reformu a efektivní veřejnou správu [online]. Praha, Ministry of the Interior of the Czech Republic, [cited $11^{\text {th }}$ September, 2012], $<$ www.mvcr.cz/clanek/zavery-jednani-gremia-748043.aspx $>$.

[15] Ochrana, F. (2005): Nákladově užitkové metody ve veřejném sektoru. Praha, Ekopress, 2005. 
Vítek, L.: Regulatory Impact Assessment in the Czech Republic.

[16] OECD (2009): Regulatory Impact Analysis: A Tool for Policy Coherence. Paris, Organization for Economic Co-operation and Development, 2009.

[17] OECD (2009a): Indicators of Regulatory Management systems, 2009 Report. Paris, Organization for Economic Co-operation and Development, 2019.

[18] OECD (2010): Better Regulation in Europe - The EU 15 project. Paris, Organization for Economic Co-operation and Development, 2010.

[19] OECD (2010a): Regulatory Reform for Recovery: Lessons from Implementation during Crises. Paris, Organization for Economic Cooperation and Development, 2010.

[20] Parker, D. - Kirkpatrick, C. (2012): The Economic Impact of Regulatory Policy: A Literature Review of Quantitative Evidence. Paris, Organization for Economic Co-operation and Development, 2012.

[21] Radaelli, C. - Fritsch, O. (2012): Evaluating Regulatory Management Tools and Programmes. OECD Regulatory policy Expert Paper No. 2. Paris, Organization for Economic Co-operation and Development, 2012.

[22] Radaelli, C. M. (2010): Rationality, Power, Management and Symbols: Four Images of Regulatory Impact Assessment. Scandinavian Political Studies, 2010, vol. 33, no. 2, pp. 164-188.

[23] Radaelli, C. M. (2010a): Regulating Rule-Making via Impact Assessment. Governance-Ai International Journal of Policy Administration and Institutions, 2010, vol. 23, no. 1, pp. 89-108.

[24] Saurwein, F. (2011): Regulatory Choice for Alternative Modes of Regulation: How Context Matters. Law \& Policy, 2011, vol. 33, no. 3, pp. 334-366.

[25] Staroňová, K. (2010): Regulatory Impact Assessment: Formal Institutionalization and Practice. Journal of Public Policy, 2010, vol. 30, pp. 117-136.

[26] UV (2007): Usnesení vlády České republiky č.877 o Obecných zásadách pro hodnocení dopadi̊ regulace. Praha, Úřad vlády ČR, 2007. 
[27] UV (2007a): Obecné zásady pro hodnocení dopadi̊ regulace. Př́loha $k$ Usnesení vlády č. 877/2007. Praha, Office of the Government, 2007.

[28] UV (2012a): Obecné zásady pro hodnocení dopadi̊ regulace (RIA). [on-line], Praha, Office of the Government, [cited 15 ${ }^{\text {th }}$ August 2012], $<$ http://www.vlada.cz/assets/ppov/lrv/ria/metodiky/Obecne-zasadypro-hodnoceni-dopadu-regulace.pdf $>$.

[29] UV (2012b): Zápisy z jednáni Komise pro hodnocení dopadů regulace $v$ r. 2011 a 2012. [on-line], Praha, Office of the Government, [cited $9^{\text {th }}$ October 2012], $<$ http://www.vlada.cz/cz/ppov/lrv/ria/pracovni-komise/jednanikomise-pro-hodnoceni-dopadu-regulace-v-r--2012-97078/>.

[30] Vítek, L. (2010): Hodnocení dopadi̊ vládních regulací. In Ochrana, F. - Pavel, J. - Vítek, L. et al.: Veřejný sektor a veřejné finance (financování nepodnikatelských a podnikatelských aktivit). Praha, Grada, 2010.

[31] Vítek, L. (2011): Hodnocení dopadi̊ regulací (RIA). In Nekola, M. Geissler, H. - Mouralová, M. (eds.): Současné metodologické otázky veřejné politiky. Praha, Karolinum, p. 306, 2011.

[32] Zhang, Y. F. (2010): Towards Better Regulatory Governance? Public Management Review, 2010, vol. 12, no. 6, pp. 873-891. 


\title{
Regulatory Impact Assessment in the Czech Republic
}

\author{
Leoš VÍTEK
}

\begin{abstract}
In 2007/2008, the Czech Republic has introduced governmental Regulatory Impact Assessment (RIA) to the central government level. This procedure has established formal rules binding to all legislative bodies. The process administration of RIA was entrusted to the Panel for a Regulatory Reform and Effective Public Administration and its permanent Committee for Quality Control of the Regulatory Impact Assessment. At the end of 2011, the RIA process has been changed and a new, independent Committee for the control of RIA proposals has been established. Based on minutes from the Committee's discussions, the presented paper analyses fundamental trends in the RIA process in the 2008-2012 period. The general statistical overview indicates that the volume of legislation reviewed under RIA gradually decreases. On the other hand, the number of proposals not recommended by the Committee for an approval decreased from $7.1 \%$ in 2008 to $6.9 \%$ in 2011. After introducing the new RIA rules, the number of proposals not recommended by the new Committee for an approval during the first discussion of a proposal has dramatically increased to $81 \%$.
\end{abstract}

Key words: Czech Republic; Government policy; Regulation; Regulatory impact assessment.

JEL classification: H83, L51. 